\title{
Production Potential of Agricultural Crops under Eucalyptus tereticornis Based Agrisilviculture System in Semi-Arid Region of Haryana
}

\author{
K.S. Ahlawat, Vijay Daneva*, Chhavi Sirohi and Virender Dalal \\ Department of Forestry, CCS Haryana Agricultural University, \\ Hisar-125004 (Haryana), India \\ *Corresponding author
}

\section{Keywords}

Agroforestry,

Winter crops, Eucalypts, Spacing, Yield

Article Info

Accepted:

20 May 2019

Available Online:

10 June 2019

\section{A B S T R A C T}

This experiment was carried out at farmer's field to evaluate the performance of different agricultural crops under eucalypts plantation (establishment of plantation on September, 2014) at a spacing of $3.9 \times 1.5 \mathrm{~m}$ during Rabi season 2014-15 and 2015-16, respectively. After 2 years of plantation, yield of agricultural crops (mustard, wheat, berseem and oat) were reduced significantly under eucalypts plantation in comparison to sole crop (devoid of tree). Among all the agricultural crops, the maximum yield was recorded in berseem (6.12 and $4.94 \mathrm{t} / \mathrm{ha}$ ) which was closely followed by oat $(5.50$ and $5.19 \mathrm{t} / \mathrm{ha})$ under eucalypts plantation during both the years of experiment. The highest per cent decrease in yield over control was recorded in wheat $(18.5 \%)$ and it followed the order: mustard $(12.9 \%)>$ berseem $(7.21 \%)>$ oat $(4.47 \%)$ during $2015-16$. The yield of all the winter crops reduced significantly with the increase in age of eucalypts plantation under this study. Among the agricultural crops grown under eucalypts plantation, berseem and oat was observed significantly higher yield under study during 2014-15 and 2015-16. However, yield of other agricultural crops (wheat and mustard) was reduced remarkable in both the years of eucalypts plantation over control. On the other hand, among all the agricultural crops grown under eucalypts plantation, the maximum net return were found in oat crop (Rs. 26,535 and 14,580/ha), which was closely followed by berseem with the net returns (Rs. 8693 and 7086 /ha) during 2014-15 and 2015-16, respectively. On the basis of the above results it was found that oat crop had given higher benefit followed by berseem when it was grown under eucalypts plantation.

\section{Introduction}

Rapid population increase and consequent increase in the requirement for different kinds of paper products and the emphasis on paper as an environmentally friendly packaging material have led to increased demand for wood. The imbalance between the supply and demand for forest products is growing. Many pulp mills are finding it difficult to source wood from natural forests and find land where they can establish plantations (Puri and Nair, 2004). The majority of the mills are entering into contracts with local communities in the name of joint venture schemes for producing wood (Saxena, 1995). The yields obtained 
from on-farm plantations of exotic species have often been many times greater than those from natural forests. The acreage under eucalypts has increased rapidly in Haryana during the last decade due to the assured market, high returns from trees and supportive government policies. Tree growing has become a profitable land use with the establishment of company/farmer relationships, trading of wood in the open market, competition among paper mills to meet their wood requirements and development of wood markets.

Tree crop integration results into many types of interactions for solar radiations, soil moisture and plant nutrients, there by changing microclimate, which affect the productivity of component crop. The large crown of trees produces a striking shade effect. Because of the plant height ratio of tree-crop intercropping is far greater than in pure crops, an entirely new pattern for light utilization is formed (Whiting, 2011). The farmers adopt only those agroforestry systems, which do not adversely affect their agricultural crops for food security. However, accommodation of trees on hectare basis in the farm land without unduly affecting crops under reduced light condition of the agroforestry system still remains to be inconclusive.

A fundamental understanding of stand growth and the factors that influence it are vital to achieving and sustaining high rates of production. Doubts have been expressed about the sustainability of tropical plantations both in terms of biological productivity and their potential impact on the environment. Nutrient dynamics is very important for the understanding of ecosystem functioning and ecological status. Nutrient uptake, their retention and release are the three components of nutrient dynamics in forest ecosystem. More uptakes and less return to the soil leads to deterioration of land and ultimately lowering of productivity. Fast growing tropical tree plantations incorporate considerable amounts of nutrients in their biomass over a relatively short period of time and the nutrient concentration in various biomass components varies significantly with tree species.

Agroforestry is one of the best options to increase the tree cover outside the forest. The need of agroforestry has been necessitated in many parts of the country, which face several agricultural and ecological problems, predominant of which are soil degradation, large scale deforestation, increasing population pressure of human beings and livestock, and decreasing land: man ratio. Agroforestry is a popular tool to modify the microclimatic under field conditions. Trees mainly modify radiations, relative humidity, carbon dioxide concentration, wind velocity and soil environment to crop (Dhillon et al., 2016).

This can lead to site fertility declines, which can limit sustained plantation forestry in tropical regions. Soil fertility can decrease through excessive removal of living biomass, particularly if nutrients in tree crowns are lost through harvest or site preparation. The extensive export of nutrients related to intensive biomass extraction has raised the concern for the long term fertility of the system among forest ecologists (Blanco et al., 2005). The nutrient cost of biomass removal is partly dependent on the nutrient characteristics of the parts of the tree removed (Kumar et al., 1998). High concentrations of nutrients in small branches, twigs and leaves compared to stem are the main reason for this nutrient drain. Very intensive harvesting has also been claimed to have a negative influence on the organic matter content in forest soils due to reduced inputs of dead biomass (Jandl et al., 2007). 
Eucalyptus tereticornis commonly known as 'red gum' is native of Australia and Papua New Guinea. It is one of the most widely planted exotic species that has been extended to other parts of the globe. It has been promoted in many tropical countries owing to its fast growth rate, adaptability to wider climatic and edaphic conditions and multiple uses (Evans, 1992). Eucalypts clones have revolutionized the productivity and profitability of the plantations in many states of our country (Lal, 2005) and most popular choice to be planted along the edges or bunds of agricultural fields, and appears to be well incorporated and accepted in agroforestry in India (Tejwani, 1994). Saline and alkaline soils are of widespread occurrence in arid and semi-arid regions of northern India, which need to be revegetated profitably. In northern India farmers are cultivating different agricultural crops under different spacing's of eucalypts but the information on cultivation of agricultural crops under eucalypts based agri-silvicultural system is lacking. Although the growing of intercrops with trees was started about a decade or so ago, no effort has been made so far to analyze the effect of different ages of eucalypts plantation on the productivity of agricultural crops. Therefore, the investigation was planned to evaluate the productivity of agricultural crops and economic returns of eucalypts-based systems in comparison with that of the arable system of the region.

\section{Materials and Methods}

\section{Experimental site}

This study was, therefore, carried out on farmer's field to obtain base line data on agricultural crops under different ages (1 year and 2 years old) of eucalypts based agroforestry system. The on farm trail was conducted in Bhiwani district (Haryana) located between $28.19^{\circ}$ and $29.05^{\circ}$ north latitudes and $75.26^{\circ}$ and $76.28^{\circ}$ east longitudes. The district has a semi-arid climate with hot and dry winds in summer, severe cold in winter and humid warm weather during monsoon. The maximum temperature sometimes exceeds $47{ }^{0} \mathrm{C}$ in summer while temperature below freezing accompanied by frost in winter is usually experienced in the region. The average annual rainfall is $300-400 \mathrm{~mm}$. About $80-90 \%$ of total rainfall are received from south-west monsoon in the month of July to September while remaining 10-20\% rainfall are received from north-east monsoon in the winter season. The soils are sandy loam in texture and low in available organic carbon $(0.39 \%)$, low in available phosphorus (6 $\mathrm{kg} / \mathrm{ha})$ and medium in available potash $(121 \mathrm{~kg} / \mathrm{ha})$.

\section{Results and Discussion}

\section{Performance of different agricultural crops under eucalypts plantation}

The data presented in Table 1 showed that there was a significant reduction in the yield of agricultural crops (mustard, wheat, berseem and oat) after 2 years as intercrops in eucalypts based agroforestry system as compared to control (without tree). The results revealed that among all the agricultural crops, the maximum yield was recorded in berseem (6.12 and $4.94 \mathrm{t} / \mathrm{ha})$ which was closely followed by oat (5.50 and 5.19 t/ha) under eucalypts plantation during both the years of experiments. The highest per cent decrease in yield over control was recorded in wheat $(18.5 \%)$ and it followed the order: mustard $(12.9 \%)>$ berseem $(7.21 \%)>$ oat $(4.47 \%)$ during this study (Figure 1). Similarly, Kumar and Nandal (2004) evaluated the performance of five test crops viz. wheat, beseem, potato, mustard and lentil under two and a half years old Eucalyptus tereticornis planted at $6 \times 2 \mathrm{~m}$ based agrisilviculture system. They studied that all the 
test crops sown in the interspaces of eucalypts showed reduced plant vigour in terms of plant height, stem diameter, number of branches and yield attributes as compared to control.

They found that the yield of lentil, berseem, wheat, potato and mustard under eucalypts decreased to the tune of $16.3,52.1,62.3,80.8$ and 82.4 per cent, respectively. The yield of all the winter crops reduced significantly with the increase in age of eucalypts plantation.

Among the agricultural crops grown under eucalypts plantation, berseem and oat was observed significantly higher yield under study during 2014-15 and 2015-16. However, yield of other two agricultural crops (wheat and mustard) was reduced remarkable in both the years of eucalypts plantation over control.
The present findings are in close proximity with Kumar et al., (2013) who reported that the yield of wheat and mustard was significantly less under eucalypts based agroforestry system as compared to sole crop (devoid of trees). Further they studied that the parameters such as plants per running meter row length (161.7), spike length $(7.7 \mathrm{~cm})$, grains per spike (37.7) and test weight (26.7 g) were also significantly less under eucalypts than in sole cropping. The grain and straw/stover yields of both the crops under eucalypts decreased significantly as compared to sole cropping. The reduced value of yield parameters of wheat and mustard may be ascribed to competition for light, moisture and nutrients in addition to the allelopathic effect of eucalypts. Similar findings were also reported by (Deswal and Nandal, 2008).

Table.1 Effect of Eucalyptus tereticornis based agrisilviculture system on yield (t/ha) of different agricultural crops during 2014-15 and 2015-16

\begin{tabular}{|l|c|c|c|c|}
\hline \multirow{2}{*}{ Treatments } & \multicolumn{3}{|c|}{ Yield (t/ha) } \\
\cline { 2 - 5 } & \multicolumn{2}{|c|}{$\mathbf{2 0 1 4 - 1 5}$} & \multicolumn{2}{c|}{$\mathbf{2 0 1 5 - 1 6}$} \\
\cline { 2 - 5 } & $\begin{array}{c}\text { With Eucalyptus } \\
\text { tereticornis }\end{array}$ & $\begin{array}{c}\text { Control } \\
\text { (without tree) }\end{array}$ & $\begin{array}{c}\text { With Eucalyptus } \\
\text { tereticornis }\end{array}$ & $\begin{array}{c}\text { Control } \\
\text { (without tree) }\end{array}$ \\
\hline Mustard & 1.52 & 1.57 & 1.30 & 1.68 \\
\hline Wheat & 4.75 & 5.00 & 3.95 & 5.69 \\
\hline Berseem & 6.12 & 6.25 & 4.94 & 5.68 \\
\hline Oat & 5.50 & 5.75 & 5.19 & 0.99 \\
\hline C.D. at 5\% & 1.03 & 1.07 & 0.89 & \\
\hline
\end{tabular}

Table.2 Effect of Eucalyptus tereticornis based agrisilviculture system on Net Return (Profit) in Rs. /ha of different agricultural crops during 2014-15 and 2015-16

\begin{tabular}{|l|c|c|c|c|}
\hline \multirow{2}{*}{ Treatments } & \multicolumn{4}{|c|}{ Net Return (Profit) in Rs. /ha } \\
\cline { 2 - 5 } & \multicolumn{3}{|c|}{$\mathbf{2 0 1 4 - 1 5}$} & \multicolumn{2}{c|}{$\mathbf{2 0 1 5 - 1 6}$} \\
\cline { 2 - 5 } & $\begin{array}{c}\text { With Eucalyptus } \\
\text { tereticornis }\end{array}$ & $\begin{array}{c}\text { Control } \\
\text { (without tree) }\end{array}$ & $\begin{array}{c}\text { With Eucalyptus } \\
\text { tereticornis }\end{array}$ & $\begin{array}{c}\text { Control } \\
\text { (without tree) }\end{array}$ \\
\hline Mustard & 6067 & 8233 & 6889 & 21820 \\
\hline Wheat & 10925 & 15550 & 4545 & 18068 \\
\hline Berseem & 8693 & 10318 & 7086 & 34587 \\
\hline Oat & 26535 & 29785 & 14580 & \\
\hline
\end{tabular}


Fig.1 Effect of Eucalyptus tereticornis based agrisilviculture system on yield reduction (\%) of different agricultural crops over control

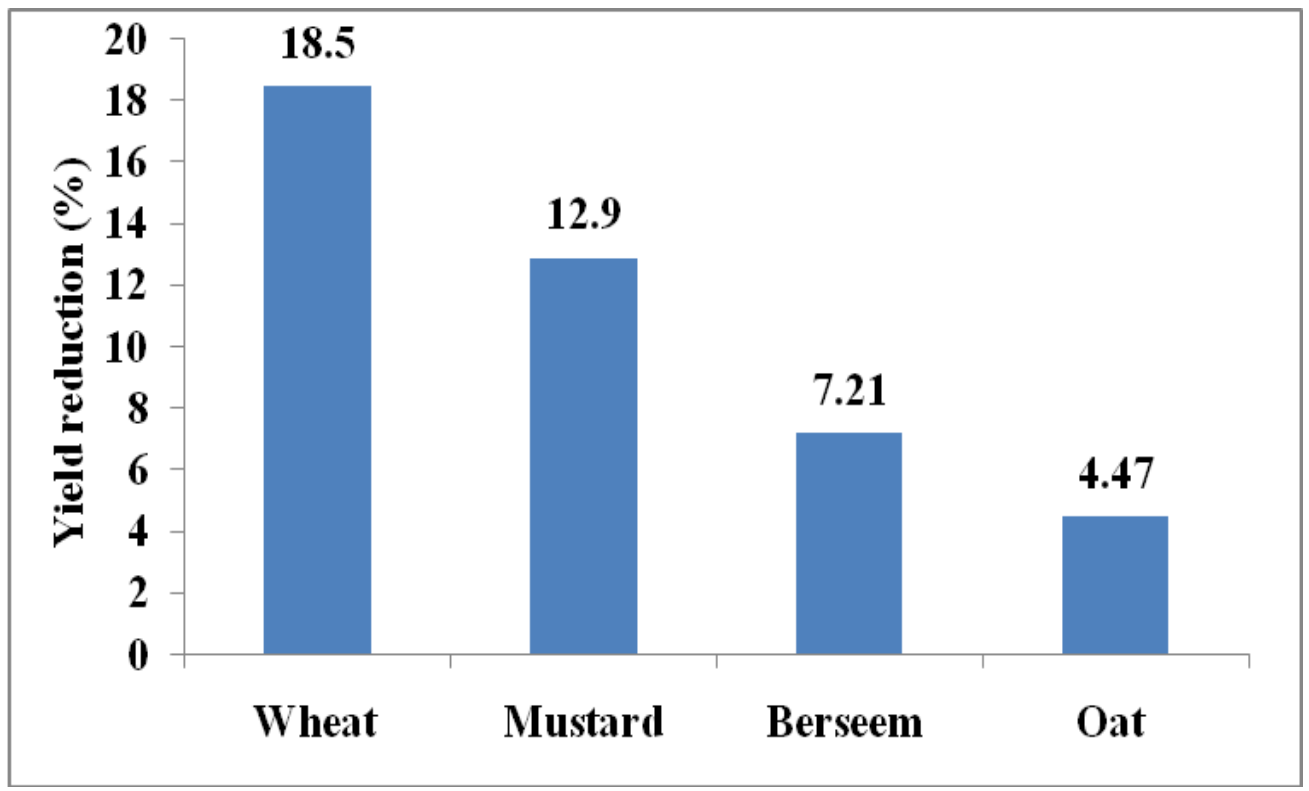

\section{Net return (Profit) Rs. /ha}

On the other hand, among all the agricultural crops grown under eucalypts plantation, the maximum net return were found in oat crop (Rs. 26,535 and 14,580/ha), which was closely followed by berseem with the net returns (Rs. 8693 and 7086 /ha) during 201415 and 2015-16, respectively (Table 2). On the basis of the above results it was found that oat crop had given higher benefit followed by berseem when it was grown under eucalypts plantation.

These results are in agreement with the findings of Prasad et al., (2010) who reported that intercropping in different wide spacing's of eucalypts gave net returns varying between Rs. 99,249 and Rs. 100,262 over a 4-year period, which were significantly greater than those from the farmers' practice of intercropping in closely spaced eucalypts (Rs 87,503), sole eucalypts (Rs. 80,435), and sole annual cropping (Rs. 27,440). All the financial parameters indicate that agroforestry based on widely spaced eucalypts is more profitable than arable cropping and the current practice of intercropping in eucalypts only in the first year. Similar conclusions were also made by Dube et al., (2002) in the case of eucalypts and by Singh et al., (1997) in the case of poplar. Modified spacing for eucalypts permitted better cash flow from improved intercrop yields over an extended period during the growth phase of eucalypts.

Based on the experimental findings, different agricultural crops grown in Eucalyptus tereticornis based agroforestry system suggested that the reduction in wheat production was maximum as compared to other winter crops. Moreover, the reduction in production of oat and berseem crop was minimum in Eucalyptus tereticornis based agroforestry system. On the basis of the present study it might be concluded that Eucalyptus tereticornis based agroforestry system was found more suitable for the maximum production of oat and berseem crop in semi-arid region of Haryana. 


\section{References}

Blanco, J.A., Zavala, M.A. Imbert, J.B. and Castillo, F.J. (2005). Sustainability of forest management practices: Evaluation through a simulation model of nutrient cycling. Forest Ecology and Management. 71: 760-762.

Deswal, A. K. and D. P. S. Nandal. (2008). Growth and yield of wheat (Triticum aestivum) under varying levels of irrigation and fertilizer in eucalyptus based agri silviculture system. Indian Journal of Agroforestry. 10(1): 10-14.

Dhillon, R.S., Bhardwaj, K.K., Beniwal, R.S., Bangarwa, K.S., Kumari, S., Godara, A.S. and Sheokand, R.N. (2016). Performance of wheat as intercrop under different spacings of poplar plantations in semi-arid ecosystem of northern India. Indian Journal of Ecology. 43: 323-327.

Dube, F., Couto, L., Silva, M.L., Leite, H.G., Garcia, R. and Araujo, G.A.A. (2002). A simulation model for evaluating technical and economic aspects of an industrial eucalyptus based agroforestry system in Minas Gerais, Brazil. Agroforestry System. 55: 73-80.

Evans, J. (1992). Plantation Forestry in Tropics. Oxford University Press, New York.

Jandl, R., Lindner, M., Vesterdal, L., Bauwens, B., Baritz, R., Hagedorn, F., Johnson, D.W., Minkkinen, K. and Byrne, K.A. (2007). How strongly can forest management influence soil carbon sequestration? Geoderma 137: 253-268.

Kumar, A. and Nandal, D.P.S. (2004). Performance of winter crops under Eucalyptus tereticornis based agroforestry systems. Indian Journal of Agroforestry. 6(2): 97-98.

Kumar, B.M., George, S.J., Jamaludheen, V. and Suresh, T.K. (1998). Comparison of biomass production, tree allometry and nutrient use efficiency of multipurpose trees grown under three age series in Kerala, India. Forest Ecology and Management. 112: 145-163.

Kumar, R., Sood, S., Kasana, R. C., Pathania, V. L., Singh, B. and Singh, R. D. (2013). Effect of plant spacing and organic mulch on growth, yield and quality of natural sweetener plant Stevia and soil fertility in western Himalayas.

International Journal of Plant Production. 8 (3): 1735-1741.

Lal, P. (2005). Integrated development of agroforestry plantations and wood based industries. In: Agroforestry in 21 century (Eds. SK Chauhan, SS Gill, SC Sharma and Rajni Chauhan). Agrotech Publishing Academy, Udaipur. pp. 296303.

Prasad, J. V. N. S., G. R. Korwar, K. V. Rao, K. Srinivas, Ch. Srinivasarao, B. Pedababu, B. Venkateswarlu, S. N. Rao and H. D. Kulkarni. (2011). On-farm evaluation of two fast growing trees for biomass production for industrial use in Andhra Pradesh, Southern India. New Forests. 42(1):51-61.

Prasad, J.V.N.S., Korwar, G.R., Rao, K.V., Mandal, U.K., Rao, C.A.R., Rao, G.R., Ramakrishna, Y.S., Venkateswarlu, B., Rao, S.N., Kulkarni, H.D. and Rao, M.R. (2010). Tree row spacing affected agronomic and economic performance of Eucalyptus -based agroforestry in Andhra Pradesh, Southern India. Agroforestry System. 78:253-267.

Puri and Nair (2004). Agroforestry research for development in India. 25 years of experiences of a national program. Agroforestry System. 61:437-452.

Saxena, N.C. (1995). Wood markets for farm eucalyptus in northwest India. In: Saxena NC, Ballabh V (eds) Farm forestry in South Asia. Sage Publications, New Delhi. 
Singh, G., Singh, N.T., Dagar, J.C., Singh, H., Sharma, V.P. (1997). An evaluation of agriculture, forestry and agroforestry practices in a moderately alkali soil in northwestern India. Agroforestry
System. 37:279-295.

Tejwani, K.G. (1994). Agroforestry in India. Oxford and IBH, New Delhi. pp 10-47.

Whiting, D. (2011). Plant growth factors: light. CMG Garden notes. 142: 1-4.

\section{How to cite this article:}

Ahlawat, K.S., Vijay Daneva, Chhavi Sirohi and Virender Dalal. 2019. Production Potential of Agricultural Crops under Eucalyptus tereticornis Based Agrisilviculture System in Semi-Arid Region of Haryana. Int.J.Curr.Microbiol.App.Sci. 8(06): 2725-2731.

doi: https://doi.org/10.20546/ijcmas.2019.806.327 